\title{
Influence of Reproductive Rhythm and Weaning Age on Fertility and Body Condition of Local Breed Does in the District of Abidjan
}

\author{
Soro Kouhana, \\ Assistant, Département Biochimie-Génétique et Département de Biologie \\ Animale, UFR Sciences Biologiques, Université Peleforo Gon Coulibaly, \\ Korhogo, Côte d'Ivoire \\ Soro Brahima, \\ Kouadio Kpandji Isidore, \\ Assistant, Laboratoire de Biotechnologies, Agriculture et Valorisation des \\ Ressources Biologiques, Unité de recherches de Génétique, UFR \\ Biosciences, Université Félix Houphouët Boigny, Côte d'Ivoire \\ Sokouri Didier Paulin, \\ Maître de Conférences, Laboratoire de Biotechnologies, Agriculture et \\ Valorisation des Ressources Biologiques, Unité de recherches de Génétique, \\ UFR Biosciences, Université Félix Houphouët Boigny, Côte d'Ivoire \\ Nguetta Bosson Austin, \\ $\mathrm{PhD}$, African Union / Interafrican Bureau for Animal Resources, \\ museum Hi 11, Westlands Roads, Nairobi, Kenya \\ Coulibaly M'Betiegue, \\ $\mathrm{PhD}$, Laboratoire Central Vétérinaire de Bingerville (LCVB), \\ Bingerville, Côte d'Ivoire \\ N'Guetta Assanvo Simon-Pierre, \\ Professeur Titulaire, Laboratoire de Biotechnologies, Agriculture et \\ Valorisation des Ressources Biologiques, Unité de recherches de Génétique, \\ UFR Biosciences, Université Félix Houphouët Boigny, Côte d'Ivoire
}

Doi:10.19044/esj.2020.v16n24p247 URL:http://dx.doi.org/10.19044/esj.2020.v16n24p247

Abstract
The objective of this study is to evaluate the reproductive performance
of locally bred rabbits by comparing the production of females mated 11
days postpartum (semi-intensive R42) with those mated 25 days postpartum
(extensive rhythm R56). Females are naturally protruding. 120 rabbits
selected from a private farm in Bingerville in the district of Abidjan were
followed during the experiment. Receptivity and gestation rates were not
significantly influenced ( $>0.05$ ) by the reproductive rhythm in the breeding 
females. Fertility in multiparous females showed a higher rate in the extensive rhythm (89-100\%). The semi-intensive rhythm had the highest stillbirth rate $(5.6 \%)$ and pre-weaning morbidity (14.03\%). However, after weaning, morbidity was higher in bunnies in the extensive rhythm (13.6\%). In the extensive rhythm, the highest values were observed for the number of weaned bunnies and the survival rate of breeding females. The extensive rhythm significantly increases the longevity of does with a high mortality rate of bunny rabbits. These results could be indicators for further investigation in the search for an optimum rate of rabbit reproduction.

Keywords: Reproductive Performance, Rabbit, Locally Breed, Reproductive Rhythm, Abidjan

\section{Introduction}

Raising rabbits is a relatively simple activity that requires very few inputs. Rabbit farming can contribute to improving the income of rabbit farmers and the diets of urban and rural households (Kacou, 1987; Bodji, 1992; Kimse et al., 2017). The galloping demography of the city of Abidjan and its suburbs constitutes a potential market for the marketing of rabbit meat. Thus, since the 2000s, rabbit breeding has been increasingly evolving, with a predominance of semi-commercial breeding (Tano, 2002).

Unfortunately, rabbit farming is not yet truly developed in Côte d'Ivoire. Indeed, it remains traditional, unlike poultry and pig farming, which are also practiced in Abidjan and its suburbs. The most common mode of reproduction is the extensive mode with 4 births per year (Kimsé et al., 2017).Very little information is available on the production system of the local breed. However recent studies (Kimsé et al., 2014; Soro et al., 2014; Kimsé et al., 2017; Samy et al., 2018) provide data on the breeding system and growth performance of rabbits.

Considered today as a developing livestock industry, improving the reproductive performance and longevity of breeding females by mastering breeding management is a key element in overcoming the difficulties associated with this type of farming (Feugier and Fortun-Lamothe, 2006). An optimum reproduction rhythm with short intervals between successive parturitions to reduce unproductive periods is of great interest. The objective of this study is therefore to evaluate the performance of locally bred breeding females based on the reproduction rhythm (semi-intensive and extensive) and the relationship between lactation and gestation. 


\section{Materials and Methods}

\subsection{Study site}

This study was carried out in a private farm located $5 \mathrm{~km}$ from the town of Bingerville, on the Bingerville-Abidjan axis. This region is characterized by abundant vegetation with sub-equatorial climate, annual rainfall averages $1.600 \mathrm{~mm}$, the temperature varies between $26^{\circ} \mathrm{C}$ and $32^{\circ} \mathrm{C}$ and the hygrometry rate exceeds $90 \%$ according to data collected from SODEXAM (Société d'Exploitation et de Développement Aéroportuaire, Aéronautique et Météorologique).

\subsection{Livestock buildings and animal monitoring}

The farm covers an area of 5 ha. It has two barns, each covered by a tarpaulin with a cemented floor. The first shed is $15 \mathrm{~m}$ long and $7 \mathrm{~m}$ wide. It shelters the breeders and the unweaned bunnies. This hutch has 70 cages. The second shed is $16 \mathrm{~m}$ long and $14 \mathrm{~m}$ wide. It is reserved for fattening bunnies and has 45 cages. The temperature and humidity are constantly monitored by means of a thermometer and a hygrometer opposite in the direction of the width.

The animals were fed with two types of granulated feed FACI and SIPRA/IVOGRAIN specially made for rabbits. The former is intended for lactating females and consists of $14.2 \%$ Crude Cellulose (CC) and $16.4 \%$ Crude Protein (CP). The second for breeding males and fattening rabbits contains $14.7 \%$ crude fibre and $15.4 \%$ crude protein. Fresh lemongrass leaves, stems, fresh or dry leaves of Moringa oleifera (Moringaceae) were also distributed to the animals. Health monitoring was carried out by a veterinary technician from the Central Laboratory of Animal Pathology in Bingerville.

\subsection{Methodology}

A total of 240 locally bred primiparous rabbits aged 17 weeks with an individual body weight between 2 and $2.2 \mathrm{~kg}$ were mated in a staggered manner. Thirty 22 -week-old locally bred breeding males weighing between 2.5 and $2.7 \mathrm{~kg}$ were used for mating; i.e. one male for every eight females. Two lots were formed. In each batch, 120 females and 15 local breed males were mated with two breeding rhythms (semi-intensive and extensive) and weaning of the bunnies (early and late) at different ages:

-lot R42: the breeding rhythm is 42 days, mating takes place 11 days after farrowing (semi-intensive rhythm). The bunnies are weaned at 35 days of age (late weaning).

-lot R56, breeding rhythm is 56 days, mating takes place 25 days after farrowing (extensive rhythm). The bunnies are weaned at 23 days of age (early weaning). 
After first parturition, females are randomly assigned to one of the follow-up lots. The animals were followed over five breeding cycles for 10 months for lot R42 and 12 months for lot R56. Pregnancy of each rabbit was monitored from the 11th day after mating by abdominal palpation. When a rabbit is pregnant, the palpation is qualified as positive.

\subsection{Statistical analysis}

The variables studied were receptivity rates (male acceptance rate at presentation), gestation, fertility, female survival, stillbirths, pre-weaning and post-weaning mortality, pre-weaning and post-weaning morbidity, litter size at birth and at weaning (rabbits born total, born live, alive at 60 days, weaned at 23 and 35 days).

The analysis focused on the comparison of the two reproductive rhythms. The comparison of the variables expressed as mean rate was done using the chi-two test $(\chi 2)$. The averages calculated from the reproductive performance data were subjected to the analysis of variance (ANOVA) with a 5\% cut-off classification criterion. When $\mathrm{p}<5 \%$, homogeneous groups were determined by Duncan's test. All these statistical analyses were performed using STATISTICA 7.1 software.

\section{Results}

3.1. Reproduction performance according to parity order

All pregnant females gave birth at first parity for each of the two rhythms. Receptivity and gestation rates did not differ significantly in breeding females at first to fifth parity for the two breeding rhythms. However, the effect of parity order on fertility was significant $(p<0.001)$. After the first parity, the fertility rate varied significantly between 90 and $87.18 \%$ for the extensive reproductive rhythm R56 ( $\mathrm{p}=0.016)$ and between 76.11 and $58.33 \%$ for the semi-intensive rhythm R42 ( $\mathrm{p}<0.001)$ (Table I). The number of bunnies born (stillbirth and live-born), the number of liveborn, the number of weaned (early and late weaning) and the number of live bunnies at 60 days of age were influenced by the order of parity in the two reproductive rhythms studied. The first parity recorded the lowest values in both rates (Table I). 
Table I: Performance of breeding females as a function of parity order

\begin{tabular}{|c|c|c|c|c|c|c|c|}
\hline Rhythm & Variables & $\begin{array}{c}\text { Parity } \\
1\end{array}$ & $\begin{array}{c}\text { Parity } \\
2\end{array}$ & $\begin{array}{c}\text { Parity } \\
3\end{array}$ & $\begin{array}{c}\text { Parity } \\
4\end{array}$ & $\begin{array}{l}\text { Parity } \\
5\end{array}$ & $\begin{array}{c}\text { Parity effect } \\
\text { p }\end{array}$ \\
\hline \multirow{7}{*}{$R 42$} & Receptivity & $100 \%$ & $92.50 \%$ & $92.92 \%$ & $84.09 \%$ & $86.15 \%$ & $0.089^{\mathrm{ns}}$ \\
\hline & Gestation & $100 \%$ & $89.17 \%$ & $85.84 \%$ & $72.73 \%$ & $70.77 \%$ & $0.195^{\mathrm{ns}}$ \\
\hline & Fertility & $100 \%^{\mathrm{a}}$ & $58.33 \%^{\mathrm{c}}$ & $76.11 \%^{\mathrm{b}}$ & $61.36 \%^{\mathrm{c}}$ & $61.54 \%^{\mathrm{c}}$ & $<0.001^{* * *}$ \\
\hline & Born total & $5.83^{\mathrm{c}}$ & $6.69 \mathrm{~b}^{\mathrm{a}}$ & $6.94^{\mathrm{a}}$ & $6.41^{\mathrm{b}}$ & $5.73^{\mathrm{c}}$ & $<0.001^{* * *}$ \\
\hline & Born alive & $5.48^{\mathrm{b}}$ & $6.37^{\mathrm{a}}$ & $6.45^{\mathrm{a}}$ & $6.10^{\mathrm{a}}$ & $5.55^{\mathrm{b}}$ & $0.005^{*}$ \\
\hline & Weaned at 35 days & $4.60^{\mathrm{b}}$ & $5.90^{\mathrm{a}}$ & $5.60^{\mathrm{a}}$ & $5.54^{\mathrm{a}}$ & $4.88^{\mathrm{b}}$ & $0.002^{*}$ \\
\hline & Alive at 60 days & $4.44^{\mathrm{b}}$ & $5.63^{\mathrm{a}}$ & $5.37^{\mathrm{a}}$ & $5.46^{\mathrm{a}}$ & $4.65^{\mathrm{b}}$ & $0.005^{*}$ \\
\hline \multirow{7}{*}{$R 56$} & Receptivity & $100 \%$ & $95.83 \%$ & $94.02 \%$ & $96.30 \%$ & $94.00 \%$ & $0.167^{\mathrm{ns}}$ \\
\hline & Gestation & $100 \%$ & $93.33 \%$ & 94.02 & $93.52 \%$ & $94 \%$ & $0.236^{\mathrm{ns}}$ \\
\hline & Fertility & $100 \%^{\mathrm{a}}$ & $90 \%{ }^{\mathrm{b}}$ & $87.18 \%^{\mathrm{b}}$ & $90.74 \%^{\mathrm{b}}$ & $89 \%^{\mathrm{b}}$ & $0.016^{*}$ \\
\hline & Born total & $5.72^{\mathrm{b}}$ & $6.91^{\mathrm{a}}$ & $6.99^{\mathrm{a}}$ & $6.59^{\mathrm{a}}$ & $6.76^{\mathrm{a}}$ & $<0.001^{* * *}$ \\
\hline & Born alive & $5.52^{\mathrm{b}}$ & $6.68^{\mathrm{a}}$ & $6.81^{\mathrm{a}}$ & $6.48^{\mathrm{a}}$ & $6.58^{\mathrm{a}}$ & $<0.001^{* * *}$ \\
\hline & Weaned at 35 days & $5.13^{\mathrm{b}}$ & $6.27^{\mathrm{a}}$ & $6.38^{a}$ & $6.04^{\mathrm{a}}$ & $6.11^{\mathrm{a}}$ & $<0.001^{* * *}$ \\
\hline & Alive at 60 days & $4.88^{c}$ & $5.64^{\mathrm{ab}}$ & $5.84^{\mathrm{a}}$ & $5.45^{\mathrm{b}}$ & $5.28^{\mathrm{bc}}$ & $<0.001^{* * *}$ \\
\hline
\end{tabular}

\subsection{Performance of breeding females as a function of the rhythm of reproduction}

Reproduction rhythm has no significant effect on receptivity $(\mathrm{p}>0.05)$ (Table II). However, sexual receptivity to parity 4 is significantly affected by reproductive rhythm $(\mathrm{p}=0.003)$. Indeed, with the extensive rhythm $\mathrm{R} 56$, the sexual receptivity rate recorded is $96.30 \%$ compared to $84.09 \%$ for the semiintensive rhythm R42. After the second gestation, the next three gestations are influenced by the reproductive rhythm $(\mathrm{p}<0.05)$. The third, fourth and fifth parity pregnancy rates of females in the semi-intensive rhythm R42, $85.84,72.73$ and $70.77 \%$, respectively, are lower than those recorded in breeding females in the extensive rhythm R56, 94.02, 93.52 and 91\%, respectively. Fertility in multiparous females is influenced by the reproductive rhythm $(\mathrm{p}<0.05)$ with a higher rate in females of the extensive rhythm R56 (90; 87.18; 90.74 and 89\%) (Table II).

Table II: Maternal aptitudes of females as a function of reproductive rhythm

\begin{tabular}{ccll}
\hline Variables (\%) & $\mathbf{R 4 2}$ & $\mathbf{R 5 6}$ & $\mathbf{p}$ \\
\hline Receptivity to parity 1 & 100 & 100 & - \\
Receptivity to parity 2 & 92.50 & 95.83 & $0.273^{\text {ns }}$ \\
Receptivity to parity 3 & 92.92 & 94.08 & $0.738^{\text {ns }}$ \\
Receptivity to parity 4 & $84.10^{\mathrm{b}}$ & $96.30^{\mathrm{a}}$ & $0.003^{*}$ \\
Receptivity to parity 5 & 86.15 & 94 & $0.088^{\text {ns }}$ \\
\hline
\end{tabular}




\begin{tabular}{lclc}
\hline Gestation to parity 1 & 100 & 100 & - \\
Gestation to parity 2 & 89.17 & 93.33 & $0.256^{\mathrm{ns}}$ \\
Gestation to parity 3 & $85.84^{\mathrm{b}}$ & $94.02^{\mathrm{a}}$ & $0.039^{*}$ \\
Gestation to parity 4 & $72.73^{\mathrm{b}}$ & $93.52^{\mathrm{a}}$ & $<0.001^{* * *}$ \\
Gestation to parity 5 & $70.77^{\mathrm{b}}$ & $91^{\mathrm{a}}$ & $<0.001^{* * *}$ \\
\hline Fertility to parity 1 & 100 & 100 & - \\
Fertility to parity 2 & $58.33^{\mathrm{b}}$ & $90^{\mathrm{a}}$ & $<0.001^{* * *}$ \\
Fertility to parity 3 & $76.11^{\mathrm{b}}$ & $87.18^{\mathrm{a}}$ & $0.030^{*}$ \\
Fertility to parity 4 & $61.36^{\mathrm{b}}$ & $90.74^{\mathrm{a}}$ & $<0.001^{* * *}$ \\
Fertility to parity 5 & $61.54^{\mathrm{b}}$ & $89^{\mathrm{a}}$ & $<0.001^{* * *}$ \\
*: significant effect at p $p$ 0.05; *** highly significant effect at p $<0.001 ;$ ns: non- \\
significant effect at p $>$ 0.05; In each row, means with the same letter are not significantly \\
different at p=0.05
\end{tabular}

The average number of bunnies born did not change for both breeding rates $(\mathrm{p}>0.05)$ up to the fifth parity. At the 5th parturition, the number of neonatal pups in the extensive rhythm R56 was higher $(\mathrm{p}<0.01)$. Indeed, with the extensive rhythm R56, on average one more bunny rabbit is observed compared to the semi-intensive rhythm R42 (6.58 versus 5.55 bunnies). Two months after farrowing, the number of live bunnies at 60 days per parity did not vary significantly $(p>0.05)$, regardless of the reproduction rhythm. For the number of weaned rabbits, the highest values were obtained with the extensive R56 rhythm at parities 1, 3 and 5 (Table III).

Table III: Performance of females as a function of reproductive rhythm

\begin{tabular}{lccc}
\hline Variables & $\begin{array}{c}\text { R42 } \\
\text { Means }\end{array}$ & $\begin{array}{c}\text { R56 } \\
\text { Means }\end{array}$ & p \\
\hline Number of bunnies born at parity 1 & 5.83 & 5.72 & $0.579^{\mathrm{ns}}$ \\
Number of bunnies born at parity 2 & 6.69 & 6.91 & $0.341^{\mathrm{ns}}$ \\
Number of bunnies born at parity 3 & 6.94 & 6.99 & $0.843^{\mathrm{ns}}$ \\
Number of bunnies born at parity 4 & 6.44 & 6.59 & $0.534^{\mathrm{ns}}$ \\
Number of bunnies born at parity 5 & $5.73^{\mathrm{b}}$ & $6.75^{\mathrm{a}}$ & $<0.001^{* * *}$ \\
\hline Number of bunnies born alive at parity 1 & 5.48 & 5.52 & $0.844^{\mathrm{ns}}$ \\
Number of bunnies born alive at parity 2 & 6.37 & 6.68 & $0.203^{\mathrm{ns}}$ \\
Number of bunnies born alive at parity 3 & 6.45 & 6.81 & $0.145^{\mathrm{ns}}$ \\
Number of bunnies born alive at parity 4 & 6.09 & 6.40 & $0.228^{\mathrm{ns}}$ \\
Number of bunnies born alive at parity 5 & $5.55^{\mathrm{b}}$ & $6.58^{\mathrm{a}}$ & $<0.001^{* * *}$ \\
\hline Number of bunnies weaned at parity 1 & $4.60^{\mathrm{b}}$ & $5.13^{\mathrm{a}}$ & $0.027^{*}$ \\
Number of bunnies weaned at parity 2 & 5.90 & 6.27 & $0.152^{\mathrm{ns}}$ \\
Number of bunnies weaned at parity 3 & $5.60^{\mathrm{b}}$ & $6.38^{\mathrm{a}}$ & $0.011^{*}$ \\
Number of bunnies weaned at parity 4 & 5.54 & 6.04 & $0.095^{\mathrm{ns}}$ \\
Number of bunnies weaned at parity 5 & $4.88^{\mathrm{b}}$ & $6.11^{\mathrm{a}}$ & $<0.001^{* * *}$ \\
\hline Number of live bunnies at 60 days at parity 1 & 4.44 & 4.88 & $0.061^{\mathrm{ns}}$ \\
Number of live bunnies at 60 days at parity 2 & 5.63 & 5.64 & $0.969^{\mathrm{ns}}$
\end{tabular}


Number of live bunnies at 60 days at parity 3

*: significant effect at $p<0.05 ; * * *$ highly significant effect at $p<0.001 ;$ ns: nonsignificant effect at $p>0.05$ In each row, means with the same letter are not significantly different at $p=0,05$.

At 3rd and 4th parity, the survival rate of breeding females decreases when driven at the semi-intensive R56 rhythm (Table IV). Before weaning, mortality of bunnies was higher in the semi-intensive R56 rhythm. After weaning, mortality of bunnies weaned at 23 days in the semi-intensive rhythm was significantly higher $(9.26$ versus $2.66 \%)$ than that of bunnies weaned at 35 days in the extensive rhythm $(\mathrm{p}<0.001)$. On the other hand, the semi-intensive rhythm had the highest pre-weaning stillbirth and morbidity. However, post-weaning morbidity was greater in the R56 extensive rhythm (Table V).

Table IV: Survival rate of females by reproductive rhythm

\begin{tabular}{|c|c|c|c|}
\hline Parity & $\begin{array}{c}\text { Survival rate }(\%) \\
(\mathbf{R 4 2})\end{array}$ & $\begin{array}{c}\text { Survival rate } \\
(\%)(\text { R56) }\end{array}$ & $\mathbf{p}$ \\
\hline Parity 1 & $\begin{array}{c}\mathrm{N}=120 \\
100 \\
(120) \\
\end{array}$ & $\begin{array}{c}\mathrm{N}=120 \\
100 \\
(120) \\
\end{array}$ & - \\
\hline Parity 2 & $\begin{array}{c}\mathrm{N}=120 \\
94.17 \\
(113)\end{array}$ & $\begin{array}{c}\mathrm{N}=120 \\
97.50 \\
(117)\end{array}$ & $1.96^{\mathrm{ns}}$ \\
\hline Parity 3 & $\begin{array}{c}N=113 \\
77.88 \\
(88)\end{array}$ & $\begin{array}{c}N=117 \\
92.31 \\
(108)\end{array}$ & $0.002^{*}$ \\
\hline Parity 4 & $\begin{array}{c}\mathrm{N}=88 \\
73.86 \\
(65) \\
\end{array}$ & $\begin{array}{c}\mathrm{N}=108 \\
92.59 \\
(100)\end{array}$ & $<0.001^{* * *}$ \\
\hline Parity 5 & $\begin{array}{c}N=65 \\
\mathbf{8 0 . 0 0} \\
(52)\end{array}$ & $\begin{array}{c}N=100 \\
96.00 \\
(96)\end{array}$ & $<0.001^{* * * *}$ \\
\hline
\end{tabular}

$\bar{N}=$ total number of females present at the beginning of the corresponding parity; the number of live females at the end of the parity is in brackets (...)*: significant effect at $p<0.05$; *** very significant effect at $p<0.001$; ns: non-significant effect at $p>0.05$ 
Table V: Mortality and morbidity rates of bunny rabbits according to reproduction rhythm

\begin{tabular}{|c|c|c|c|}
\hline Mortality rate $(\%)$ & R42 & R56 & $\mathrm{p}$ \\
\hline \multirow[t]{2}{*}{ Stillbirth $(\%)$} & $\mathrm{N}=2340$ & $\mathrm{~N}=3392$ & $<0.001^{* * * *}$ \\
\hline & $\begin{array}{c}\mathbf{5 . 6 0} \\
(131)\end{array}$ & $\begin{array}{c}\mathbf{2 . 9 8} \\
(101)\end{array}$ & \\
\hline \multirow[t]{2}{*}{ Pre-weaning mortality (\%) } & $\mathrm{N}=2209$ & $\mathrm{~N}=3291$ & $<0.001^{* * * *}$ \\
\hline & $\begin{array}{l}\mathbf{1 2 . 1 3} \\
(268)\end{array}$ & $\begin{array}{l}\mathbf{6 . 4 4} \\
(212)\end{array}$ & \\
\hline \multirow[t]{2}{*}{ Post-weaning mortality (\%) } & $\mathrm{N}=1941$ & $\mathrm{~N}=3079$ & $<0.001^{* * * *}$ \\
\hline & $\begin{array}{l}\mathbf{3 . 6 6} \\
(71)\end{array}$ & $\begin{array}{c}9.26 \\
(285)\end{array}$ & \\
\hline \multirow[t]{2}{*}{ Pre-weaning morbidity (\%) } & $\mathrm{N}=2209$ & $\mathrm{~N}=3291$ & $<0.001^{* * * *}$ \\
\hline & $\begin{array}{l}\mathbf{1 4 . 0 3} \\
(310)\end{array}$ & $\begin{array}{c}\mathbf{9 . 3 9} \\
(309)\end{array}$ & \\
\hline \multirow[t]{2}{*}{ Post-weaning morbidity (\%) } & $\mathrm{N}=1941$ & $\mathrm{~N}=3079$ & $<0.001^{* * * *}$ \\
\hline & $\begin{array}{c}\mathbf{9 . 8 9} \\
(192)\end{array}$ & $\begin{array}{l}\mathbf{1 3 . 6 0} \\
(420)\end{array}$ & \\
\hline
\end{tabular}

$N:$ Total Number of bunnies present at the beginning. The numbers in brackets (...) represent number of dead or morbid (sick) bunnies; *** highly significant effect at $p<$ 0.001

\section{Discussion}

This study showed that the reproductive rhythm does not significantly influence the receptivity and gestation of primiparous females. The origin and determinism of the phenomenon of mating acceptance or refusal remains very poorly known in rabbits according to Fortun-Lamothe et al. (1995). However, according to the work of Stoufflet et Caillot (1988), low receptivity is associated with a small number of pre-ovulatory follicles. Sexual behaviour, particularly male acceptance, is dependent on ovarian steroids. Estrogens and androgens promote male acceptance, while progesterone, whose role on receptivity is not fully established, is thought to have a depressant effect.

The observed fertility and gestation rates of females were higher than those reported by Gacem et al. (2009) in local rabbit populations in Algeria, bred naturally in semi-intensive breeding. These rates are nevertheless similar to the $87-90 \%$ rates reported by Akpo et al. (2018) after artificial insemination in Benin. According to Koutinhouin et al. (2009), receptivity and fertility rate are intrinsically linked parameters. The highest stillbirth rate at the semi-intensive rhythm (5.6\%) is similar to those reported by Akpo et al (2018) and Fellous et al (2012). Zerrouki et al. (2005) in Algeria and Kpodekon et al. (2004) in Benin reported higher stillbirth rates with $16.4 \%$ and 5.3 to $12.2 \%$ respectively. Rearing conditions (feeding and care) and farrowing outside nests are factors that favour stillbirths. 
An extensification of the reproduction rhythm coupled with early weaning improves the fertility of primiparous females (90\% versus $58.33 \%$ ). These results are similar with those obtained by many authors including Mendez et al (1986); Cervera et al (1993); Xiccatto et al (2004); Castellini et al (2006). This positive effect of extensification of the reproductive rhythm on fertility is also observed in multiparous females. On the contrary, the results of Feugier and Fortun-Lamothe (2006) indicated that the reproductive rhythm does not influence the fertility of multiparous females. The extensive reproductive rhythm also increases the length of the productive career of females (survival rate of $96 \%$ of breeding females from the extensive rhythm to the fifth parity versus $80 \%$ from the semi-intensive rhythm to the fifth parity). Consistent with the results of Castellini et al (2006), the results of this study show that extensification of the reproductive rhythm does not increase the prolificity of females at farrowing. However, the results of Mendez et al. (1986), Cervera et al. (1993) show an increase in litter size at birth when the reproduction rhythm is more extensive. These differences could be related to the heterogeneity of the experimental models used. On the one hand, the effect of extensification is assessed by comparing different reproduction rhythm according to the studies (intensive, semi-intensive and/or extensive) with different breeds of females, either by natural mating or artificial insemination. On the other hand, the effects of parity and reproductive rhythm on female prolificity are not really dissociated in this study. The pathological problems encountered in this study were mainly bacterial diseases. According to Boiti et al (1999) and Boucher and Nouaille (1999), these bacterial diseases can lead to reduced fertility and increased risk of abortion.

The combined action of an extensification of the reproductive rhythm and a reduction in the duration of lactation increases the longevity of females. Indeed, the reduction in lactation allows breeding females to conserve energy reserves, contrary to the semi-intensive rhythm where gestation and lactation are superimposed. The superimposed of these two states requires a high energy expenditure. It leads to bodily degradation of the females, which can cause their death. According to Kalbfleich and Pentice (1980) and Ducrocq et al. (1988), a specific study on the survival of females in reproduction would contribute to the description of their career length based on several functions of time.

The mortality of early-weaned bunnies at 23 days is much higher than that of late-weaned bunnies at 35 days. This result is similar to those of Feugier and Fortun-Lamothe (2006); Gidenne and Fortun-Lamothe (2005). These authors showed that early weaning increases the susceptibility of bunnies to digestive disorders. Thus, in the health context of farms in Abidjan district, early weaning (at 23 days) without antibiotic treatment as a 
preventive measure seems too risky. A few additional days of lactation could allow the rabbit's digestive system to reach sufficient maturity and thus avoid the digestive disorders observed after weaning at 23 days. However, studies on the influence of age at weaning on the health of the young rabbits have shown contradictory results. Indeed, studies by Prud'hon and Bel (1968), Piattoni et al (1999), Xiccato et al (2000) did not reveal any significant effect of early weaning on mortality. On the other hand, MacNitt and Moody (1992) and Ferguson et al. (1997) observed that early weaning at 14 days is detrimental to the health of the bunnies. Gidienne and Fortun-Lamothe (2005) also recorded higher mortality (17 versus 9\%) between 32 and 45 days of age when the bunnies were weaned earlier, despite the distribution of a specific post-weaning feed.

\section{Conclusion}

The present study showed that the reproductive rhythm does not influence the receptivity and gestation of primiparous females. Despite the increase in the regularity of reproductive performance and the length of the productive career, extensive management did not compensate for the loss of production due to the increase in the interval between calving. It does, however, reduce the mortality rate and optimize female fertility. Extensive management of reproduction is therefore likely to reduce the rate of renewal of breeding females in rabbit farms.

The consequences of reproductive rhythm on female performance differ for primiparous and multiparous females. This effect of the weaning-breeding interval on the reproductive performance of females requires further investigation. In addition to reproductive rhythm, genetic type could affect reproductive performance. It would then appear necessary to study these performances in different populations, hence the interest of a study on the evaluation of genetic performance.

\section{Acknowledgements}

This study was carried out within the framework of the genetic improvement program of the zootechnical performance of rabbits reared in the outskirts of Abidjan city. Program initiated by the Director of the Central Laboratory of Pathology and Virology (former Director of the National Centre for Artificial Insemination (CNIA) of Bingerville). The authors would like to thank all the rabbit breeding technicians on the various farms.

\section{References:}

1. Akpo, Y, Dotché, I.O., Tobada, P., Djago, Y., Youssao Abdou Karim, I., Kpodékon, M. T. (2018). Insémination artificielle des lapins de race commune au Bénin : dilueurs à base de produits 
locaux. Livestock Research for Rural Developmen,t 30 (8) 2018. www.lrrd.org/lrrd30/8/cont3008.htm

2. Bodji, N. C. (1992). Elevage actuel en Côte d'ivoire : situation actuelle et perspective d'avenir. Premier congrès régional de cuniculture, 15-20 mars 1992 Cotonou (Bénin): 1-4.

3. Boiti, C., Canali C., Brecchia G., Zanon, F., Facchin, E. (1999). Effects of induced endometritis on the life-span of corpora lutea in pseudopregnant rabbits and incidence of spontaneous uterine infections related to fertility of breeding does. Theriogenology, 52(7): 1123-1132. doi.org/10.1016/S0093-691X(99)00204-6

4. Boucher, S., Nouaille, L. (1999). A propos de 22 cas de klebsielose à Klebsiella pneumoniae dans des élevages cunicoles rationnels des Pays de Loire. 8èmes Journées de la Recherche Cunicole France, Paris, 9-10/06/1999.

5. Castellini, C., Dal Bosco, A., Cardinali, R. (2006). Long term effect of post weaning rhythm on the body fat and performance of rabbit doe. Reproduction Nutrition Development 46(2):195-204. DOI:10.1051/rnd:2006009

6. Cervera, C., Fernandez-Carmona, J., Viudes De Castro P., Blas, E. (1993). Effect of remating interval and diet on the performance of female rabbits and their litters. Animale Science, 56(3), 399-405. DOI: https://doi.org/10.1017/S0003356100006450

7. Ducrocq, V., Quaass, RL., Pollack, E.J., Casella, G. (1988). Length of productive life of dairy cows. 1.Justification of a Weibull model, Journal of Dairy Science, 71(11): 3061-3070. DOI: https://doi.org/10.3168/jds.S0022-0302(88)79906-3

8. Fellous, N., Reguig, K and AinBaziz, H. (2012). Evaluation des performances zootechniques de reproduction des lapines de population locale algérienne élevées en station expérimentale. Livestock Research for Rural Development 24 (3), http://lrrd.cipav.org.co/lrrd24/3/fell24051.htm

9. Ferguson, F.A., Lukefahr, S.D., Mcnitt, J. I. (1997). A technical note on artificial milk feeding of rabbit kits weaned at 14 days. World Rabbit Science, 5(2): 65-70. DOI: https://doi.org/10.4995/wrs.1997.321

10. Feugier, A., Fortun-Lamothe, L. (2006). Extensive reproductive rhythm and early weaning improve body condition and fertility of rabbit does. Animal Ressource, 55(5): 459-470. DOI: 10.1051/animres:2006025

11. Fortun-Lamothe, L., Bolet, G. (1995). Les effets de la lactation sur les performances de reproduction chez la lapine. INRA Production Animale, 8(1): 49-56. 
12. Gacem, M., Zerrouki, N., Lebas, F., Boley, G. (2009). Comparaison des performances de production d'une souche synthétique de lapins avec deux populations locales disponibles en Agérie. 13ème Journées de la Recherche Cunicole, 17-18 novembre 2009. 4p.

13. Gidenne, T., Fortun-Lamothe, L. (2005). Growth, health status and digestion of rabbits weaned at 23 or 32 days of age. In Proceeding of the 8th World Rabbit Congress, Editions WRSA World Rabbit Science Associated, Puebla, Mexico, 846-852.

14. Kacou, A. C. (1987). Elevage actuel en CI: situation actuelle et perspective d'avenir premier congrès régional de cuniculture 15-20 Mars 1992 Cotonou (Bénin). Département Elevage de l'Institut de Savane de Bouaké. Annale de techniques d'élevage, 20-30.

15. Kalbfleich, J.D., Pentice, R. L. (1980). The statistical analysis of failure time data, John Wiley and sons, New York, USA, 321 p.

16. Kimse, M., Gnanda, B.I., Beugré, G.A.M., Bodji, N.C., Fantodji, A. (2014). Effect of associated using of commercial feed supplementation and green forage on rabbit (oryctolagus cuniculus) growth and health. Scientia Agriculturae, 6(3): 114-119. DOI: 10.15192/PSCP.SA.2014.2.3.114119

17. Kimse, M., Coulibaly, A.S., Gnanda, B.I., Zongo, M., Yapi, Y.M., Fantodji, T.A., Otchoumou, A. A. (2017). Caractérisation des systemes d'élevage cunicoles dans le district d'Abidjan (Côte d'Ivoire). Agronomie Africaine, 29 (2), 185-196.

18. Koutinhouin, G.B, Youssao, A.K.I., Kpodekon, T.M., Djago, Y and Houenon, R. (2009). Incidence de la séparation mère-portée sur la fertilité des lapines allaitantes et la taille de la portée au Sud du Bénin. Bulletin de la Recherche Agronomique du Bénin, 66, pp 1318.

19. Kpodekon, M., Djago, Y., Farougou, S., Coudert, P. and Lebas, F. (2004). Results of the technical management of four rabbit farms in Benin. Proceedings - 8th World Rabbit Congress -September 7-10 2004 - Puebla, Mexico, pp 555-561. https://world-rabbitscience.com/WRSA-Proceedings/Congress-2004-

Puebla/Papers/Management-\&-Economy/M-Kpodekon.pdf

20. Mac Nitt, J.I., Moody, G.L. (1992). A method for weaning rabbit kits at 14 days. Journal Applied to Rabbit Ressource, 15, 661-665.

21. Mendez, J., Blas, J.C., Fraga, M.J. (1986). The effects of diet and remating interval after parturition on the reproductive performance of the commercial doe rabbits, Journal of Animal Science, 62, 16241634.

22. Piattoni, F., Maertens, L., Mazzoni, D. (1999). Effect of weaning age and solid feed distribution before weaning on performances and 
caecal traits of young rabbits. Cahiers Options Méditerranéennes, 41, 85-91.

23. Prud'hon, M., Bel, L. (1968). Le sevrage précoce des lapereaux et la reproduction des lapines. Annale de Zootechnie, 17(1): 23-30.

24. Samy, T., Tian-Bi, Y.N., Sokouri, D.P., N'Guetta, A.S.P. (2018). Genetic analysis of some zootechnical performances in the breed hyplus of the rabbit, Oryctolagus cuniculus, raised in Côte d'Ivoire. International Journal of Biosciences, 14(4): 46-54

25. Soro, K., Sokouri, D.P., Bosso., N.A., Coulibaly, M., N'Guetta, A.S.P. (2014). Genetic parameters of some production traits of the synthetic breed Cunistar MDL (Minimum Disease Level). International Journal of Agronomy and Agricultural Research 4, 110118.

26. Stoufflet, L., Caillol, M. (1988). Relations between sex steroids concentrations and sexual behavior during pregnancy and postpartum in the domestic rabbit. Journal of Reproduction and Fertility, 82(1): 209-218. DOI:10.1530/jrf.0.0820209

27. Tano, K. J. (2002). Contribution à l'étude des contraintes au développement de la cuniculture en Côte d'Ivoire: Région d'Abidjan, Thèse Médecine Vétérinaire, Université de Cocody, Abidjan, Côted'Ivoire, p. 150.

28. Xiccato, G., Trocino, A., Sartori, A., Queaque, P. I. (2004). Effect of parity order and litter weaning age on the performance and body energy balance of rabbit does, Livestock Production. Science, 85(23): 239-251.https://doi.org/10.1016/S0301-6226(03)00125-8

29. Xiccato, G., Trocino, A., Sartori, A., Queaque, P. I. (2000). Early weaning of rabbits: effect of age and diet on weaning and postweaning performance. In 7th World Rabbit Congress, Editions World Rabbit Science Associated Congress, Valence, Spain, volume C, 483490.

30. Zerrouki, N., Kadi, S.A, Berchiche, M and Bolet, G. (2005). Evaluation de la productivité des lapines d'une population locale algérienne, en station expérimentale et dans des élevages. Proc. 11èmes Journées de la Recherche Cunicole, novembre, Paris, France, $\mathrm{n}^{\circ} 1114$. 